\title{
ポゾラン材としてのもみがら灰の有効利用に 関する基礎的研究
}

\author{
杉田 修- ${ }^{1}$. 庄谷 征美 ${ }^{2}$ \\ ${ }^{1}$ 正会員公戸工業大学土木工学科教授 \\ （テ031 青森県八戸市妙字大開88-1） \\ ${ }^{2}$ 正会員 工博 八戸工業大学土木工学科教授 \\ （テ031 青森県八戸市妙字大開88-1）
}

\begin{abstract}
もみがら焼却原理として「2 段階燒却法」を示し，その原理に基づいて設計された焼却炉の実例を示し，さらにこの 炉から生産されたもみがら灰の優れたボソラン活性をコンクリート強度試験によって確認した。また，もみがら灰の粉 碎に伴って発生する 2 次凝集粒子について検討し，これを防止する一方法として粉研助剂（ジエチレングリコール）を 用いて粉碎を行った。 その結果，粉碎助剤の使用はきわめて効果的であることが判明した。また，もみがら灰の高度な ブリーディング抑制能力を利用して高水セメント比コンクリート(水結合材比70\%)の実跧を行ったが，フリーディング はまったく観察されず，十分実用に供しうる強度のコンクリートを得ることができた。
\end{abstract}

Key Words: rice husk ash, two step burning method, electric conductivity, batch system, secondary agglomeration, grinding aids, high water binder ratio concrete

\section{1. 序}

工業分野からの廃棄物としてフライアッシュ，高 炬スラグ, ニッケルスラグ, 石炭灰, シリカフュー ム等がコンクリート用材料として有効活用が為され ていることは周知の通りである。これらに関する知 識の集積と実用面での実績は豊富に存在する. 天然 ポゾラン材として火山灰も一部実用に供されている が，農業分野からはもみがら灰の有効利用に関する 研究が最も進んでおり, 期待の出来る廃棄物である. 稲は土中から吸収する珪酸分の集積度がきわめて高 く，とくにもみがら部分に著しい。そ焼却灰（以 下 RHA と記す）中には質量で約 $90 \%$ 前後の $\mathrm{SiO}_{2}$ が 含有されている。この含有率はフライアッシュより かなり大きく，良質のシリカフュームに相当する含 有率である。葉および茎の部分はもみがらの60-70\% 位である.このような植物を農学あるいは植物学の 分野では「珪酸集積植物」と呼んでおり，稲以外に も麦, 竹, 笹, とうもろこし, 砂糖きび, とくさ (砥草) 等が存在する.

もみがら灰のポゾラン材としての本格的研究は海 外においては Mehta ${ }^{1)}$ ，わが国においては山本ら ${ }^{21}$ の研究を嚆矢とするであろう．また，オートクレー
ブによる建材の開発, セラミックス, 光ファイバー, ニューガラス等いわゆる先端材料と呼ばれている分 野に対する有効利用を最も活発に研究しているのは, わが国においては通産省であり，九州工業技術院で 開発され，1985年2月公開された建材に関する特許 ${ }^{31}$ は既に東南アジアにおいて実用に供されている.

山本らは実験室および野外の両面においてかなり 大規模な実験を行い， RHA 混入モルタル供試体に よってRHAの基礎的諸物性について多くの知見を 得ている.また，この研究の中で RHA の残留炭素 の影響について Mehtaの研究の誤りを正すなど多 くの成果を挙げている．さらに，世界の米生産国の 殆どがアジアの発展途上国である点を考慮して，

「高度技術の必要のない焼却設備の確立」を目標に して，示唆に富む方式を提案している．この方法は 現在著者が提案している焼却方法の中の「2段階焼 却法」に相当するものと考えられ，著者の研究結果 からも十分理解できる方法である.

もみがらは飼料としての用途は殆どなく，わが国 では一部がライスセンター運転の熱源として焼却さ れ，あるいはもみがらを破砕し，堆肥として還元使 用される以外は野焼きなどの方法で焼却処分されて いるのが現状である. 
$\mathrm{SiO}_{2}$ の鉱物資源は珪石，珪砂，石英等が挙げら れる。しかし $\mathrm{SiO}_{2}$ 含有率は高いが殆ど結晶化して おり，化学的活性は乏しい。これに対して稲は土中 から結晶化した $\mathrm{SiO}_{2}$ を吸収する際に，生体の働き によって非晶質に変換して取り込む. 化学的活性が 期待されるためには非晶率の高い $\mathrm{SiO}_{2}$ でなければ ならないことを考えると，結晶質を非晶質に変換す るこの生体作用はきわめて重要で且つ有意義なこと と言わなければならない，また，植物資源の再生産 性は鉱物資源と比較して，決定的な利点である．前 掲の鉱物資源からの $\mathrm{SiO}_{2}$ を非結晶に加工するため に，準アルミ産業と呼ばれるような莫大なエネルギ 一が消費されることを考えると，植物起源 $\mathrm{SiO}_{2}$ の 重要性の意味がよく理解できる.

本論文の構成は既往の成果 ${ }^{4)}$ ８) も踏まえつつ， 以下のような構成となっている.

1）高非晶質 RHA を得る焼却原理：2 段階焼却法

2） RHA の非晶性の判定 : $\mathrm{Ca}(\mathrm{OH})_{2}$ 飽和溶液の電気 伝導率の変化を測定するLuxanの方法

3）粉砕 RHA の2，3の性質：2 次凝集特性

4) 2 次凝集の一軽減法: 粉砕助剂（ジエチレング リコール）の効果

5） 2 段階焼却法に基づく焼却炉の設計：連続シス テムとバッチシステム

6）これら焼却炉から生産された RHAのポゾラン 活性評価：非晶性の判定およびコンクリート強 度試験

7）高水セメント比コンクリートへの RHA の適用 : 水セメント比 $70 \%$ コンクリートへの RHA 混入

\section{2. もみがらの嬈却原理}

本章では高活性もみがら灰を得る焼却原理につい て検討した．実験は市販の小型電気炉を用いて行っ たが，その諸元は以下のようである.炉内寸法は幅 $300 \mathrm{~mm}$ ，奥行き $250 \mathrm{~mm}$, 高さ $150 \mathrm{~mm}$, 容積 11.25 $\ell$, 最高温度 $1150{ }^{\circ} \mathrm{C}$, 温度上昇速度 $\left({ }^{\circ} \mathrm{C} / \mathrm{min}\right)$ の設 定, 所定温度とその維持時間の設定が可能で, 天版 の中央に直径 $50 \mathrm{~mm}$ の排気孔を有する. 予備実験 の結果, もみがらは乾燥質量 $800 \mathrm{~g}$ を直接炉内に投 入することとした。この方法で一度の焼却により約 150g の RHA が得られた。多数の焼却実験の結果， 焼却方法を図ー1に示すような二つに纏めることが できた

Method-1: 図-1に示されているように，炉内温度 を一気に所定の焼却温度まで上昇させ，その温度を 2 時間維持して焼却する。電源オフの状態で 5 時間 程度経過後 RHA を取り出す. 図中に点線で示して
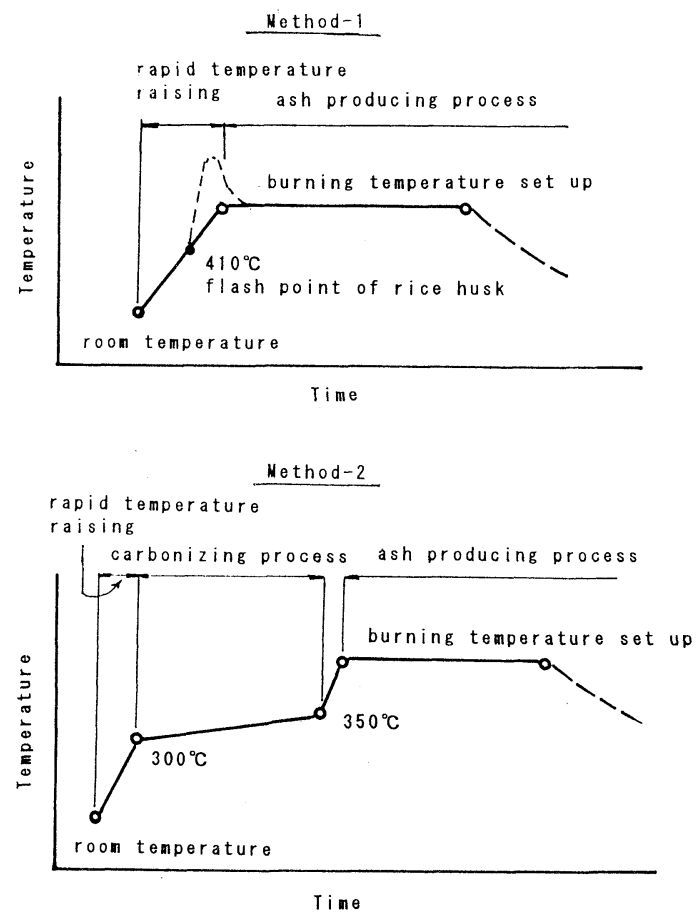

図-1もみがら焼却法法

いるように，昇温途中でもみがらは発火し，短時間 (10-15 分) ではあるが炬内温度は設定温度を超え る. 得られた RHA はやや黒い。

Method-2: 図-1に示されているように，炉内温度 を常温から $300^{\circ} \mathrm{C}$ 付近にまで一気に上昇させ， 350 ${ }^{\circ} \mathrm{C}$ 程度まで 3 時間かけてゆっくり上昇させる，その 後所定焼却温度まで一気に上昇させ， 2 時間維持し て焼却する.電源オフの状態で 5 時間経過した後 RHA を取り出す．得られた RHA はかなり白い．前 段の $350^{\circ} \mathrm{C}$ までの段階ではもみがらは発火すること なく，可燃性ガスを排出して炭化する．すなわちこ の段階は煇炭の製造過程であり，後段の所定温度に おける焼却は燻炭の焼却過程，すなわち RHA 製造 過程である．要するところ，この焼却方法は前段の 炭化過程および後段の灰化過程という 2 段階から構 成されることから，「2 段階焼却法」と呼ぶことに した。

\section{RHA の非晶性判定}

RHA の非晶性の判定には以下に述べるLuxan の 方法を採用した。Luxan らは 1989 年，ポゾラン活 性評価法の一つとして，図－2にその概要を示すよ うな迅速評価法を提案した ${ }^{9)}$ 。すなわち， $40^{\circ} \mathrm{C} に$ 管理された $\mathrm{Ca}(\mathrm{OH})_{2}$ 飽和溶液 $200 \mathrm{cc}$ を用意し，そ 


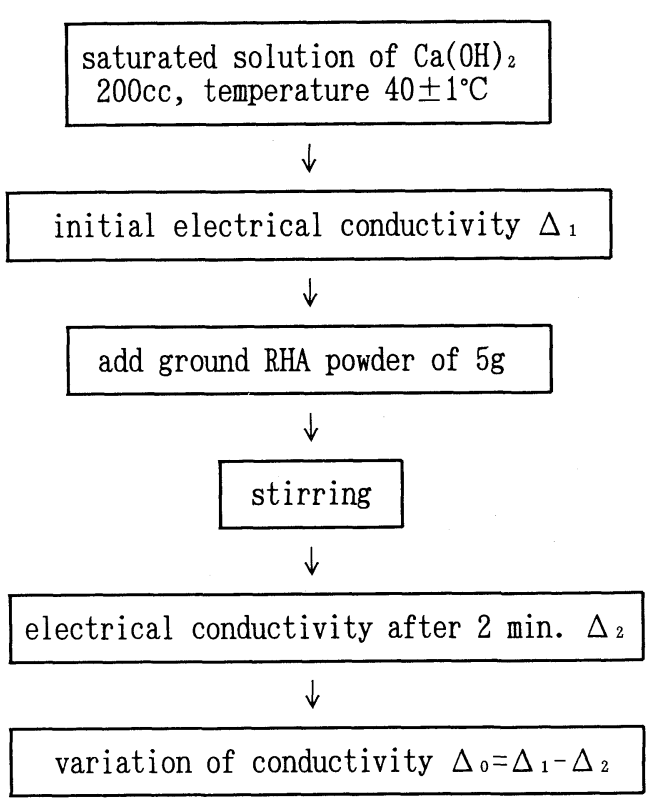

図-2 Luxanの方法

表 -1 電気伝導率差 $\Delta 。(\mathrm{mS} / \mathrm{cm})$ の評価

\begin{tabular}{|c|c|}
\hline Non & $\Delta_{0}<0.4$ \\
\hline Variable & $0.4 \leqq \Delta_{0} \leqq 1.2$ \\
\hline Good & $\Delta_{0}>1.2$ \\
\hline
\end{tabular}

の電気伝導率を測定し，これを初期值 $\Delta_{1}$ とする. 次に乾燥して適度に粉砕されたポゾラン材 $50 \mathrm{~g}$ を投 入し，擋挥しながら2分後の伝導率を測定し $\Delta_{2}$ とす る. 伝導率差 $\Delta_{0}=\Delta_{1}-\Delta_{2}$ の值がポゾラン活性の 大きさを反映し，その目安は表-1のように示されて いる. $\Delta$ 。が大きいほどポゾラン活性が大きいこと を示す。

一般に粉粒体の化学的活性の大きさは, その比表 面積と非晶性とに関係すると考えられるが, 従来こ れら二つの量はそれぞれ別個に論ぜられ，ポゾラン 材研究においてその関連が同時に考慮されることが なかった。しかしながら，Luxanの方法における 電気伝導率には，これら二つの量が同時に反映され ていると考えられるのである.それ故この方法はポ ゾラン活性を評価する指標として大変優れたもので ある.また，この方法は RHAのみならず，シリカ フュームの品質判定に対しても有効であることを確 認した ${ }^{5)}$ ・さらに，表-1に示された活性判定基準は RHAの活性評価によく適合すること，モルタル供 試体の圧縮強度と強い相関関係があること，X-線

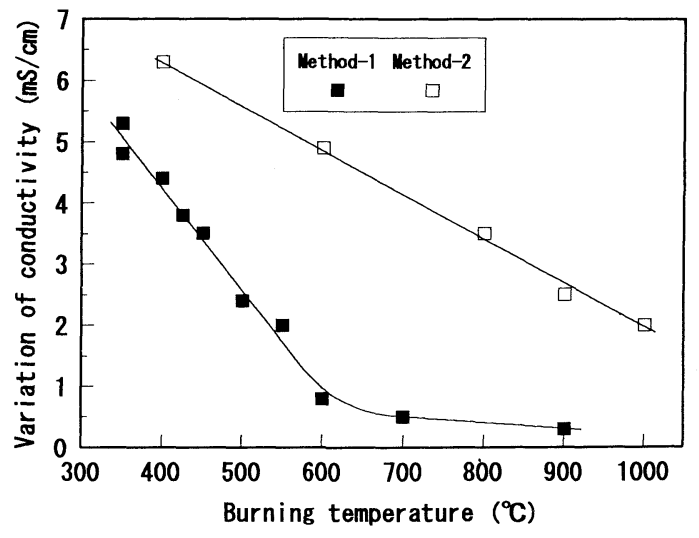

図-3 電気伝導率差と焼却温度

回折によっては判定困難な高非晶率領域 ${ }^{13)}$ におけ る非晶性の判定に有効であること等などを明らかに している5，7).

次に Method-1 および Method-2 の方法で焼却し た RHAをそれぞれ $200 \mathrm{~g}$ とり，乳鉢にて 20 分間粉 砕した試料の伝導率を測定した. 求められた伝導率 差 $\Delta$ 。と焼却温度の関係を示したのが図ー3である. この図は焼却方法の差を明瞭に示す結果となってい る.すなわち, Method-1においては $600^{\circ} \mathrm{C}$ 付近に 変曲点を有し, それ以上の温度域においては急速に 活性を失い，それ以下の温度域においては低温焼却 ほど活性が増加し，両者の関係は直線的である。 $900{ }^{\circ} \mathrm{C}$ に相当する位置のデーターはボイラー燃料灰 であり，正確な焼却温度は不明である。

Method-2においては実験の温度範囲では両者の 関係は直線的であり，変曲点を有しない， $1000^{\circ} \mathrm{C}$ において焼却された RHAでさえも $\Delta_{0} \geqq 1.2 \mathrm{mS} / \mathrm{cm}$ の值を示しており，表一 1 と照合すると良好なポソ ラン活性を示すと判断される範囲に属する.また， 直線の勾配は Method-1におけるよりは小さく, $\Delta$ 。 の温度依存性がより小さい．この点は RHA 生産現 場における品質管理に際し有利なポイントになるで あろう。このように図 -3 はアモルファスRHAを 得る方法として，「2 段階焼却法」が有利であるこ とを証明するものである。

\section{4. 实検妒の大型化と粉碎 RHA の 2 次嚗集}

粉确 RHA の 2 次凝集の存在については既に報告 ${ }^{51}$ したが，本章においてはその後の研究成果を述べる。

\section{(1)更気妒の概要および焼却方法}

3 章における研究後, もみがら焼却を目的に実験 


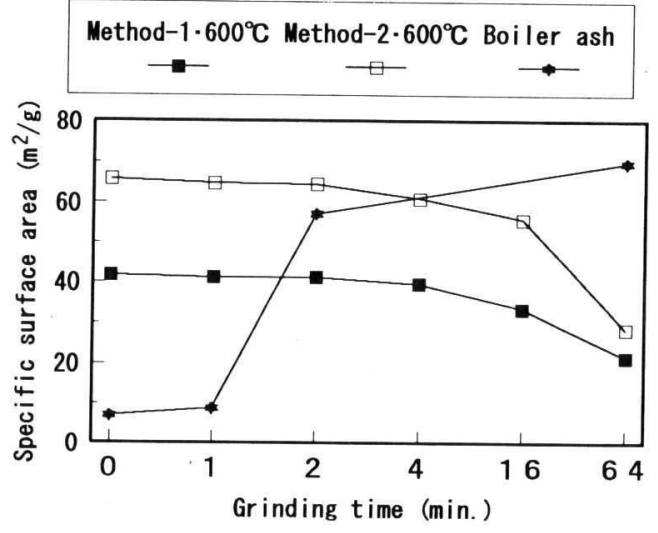

図-4 比表面積と粉砕時間

室向きの炉を製作した。内容積は前章で述べた電気 炉の約 3 倍, 最高温度 $800^{\circ} \mathrm{C}$, 最高 $450^{\circ} \mathrm{C}$ の熱風送 風可能, 排煙筒付き, 19 通りの焼却条件の設定が可 能である.もみがらを入れた2段式容器を炉内に入 れて焼却するものである. $2 \mathrm{~kg}$ のみがらを入れて， 約 $350 \mathrm{~g}$ の RHA を得ることができる.

本実験における焼却条件を図 - 1 を用いて説明す ると, Method-1および Method-2 の何れも灰化過 程における設定温度は $600{ }^{\circ} \mathrm{C}$, 維持時間は 3 時間, 以後電源を切り, もみがら投入後 24 時間で RHA を取り出した. また, 灰化過程に入ってから直ちに $450^{\circ} \mathrm{C}$ の熱風を炉内一送風し, 灰化過程終了後も 3 時間送風を継続した. Method-2における炭化過程 に対しては 4 時間を維持した。得られた RHA は Method-1 の場合は薄い灰色であり, Method-2の 場合は白色であった。このように, 前章と本章では 用いた RHAの由来が異なることをお断りしておく.

\section{（2）粉砕時間と比表面樌の関係}

Method-1 および Method- 2 の $600^{\circ} \mathrm{C}$ 焼却 RHA, ボイラー燃料灰について粉砕時間と比表面積 (窒素 吸着法による)の関係の一例を図 -4 に示す。振動 式ボールミルを用いて粉砕した。

未粉砕のものは Method-2, Method-1, ボイラ 一灰の順に小さくなっている. 粉砕時間が長くなる にしたがって前二者の比表面積は漸次減少し, 後者 のそれは增加している。一般に物質は粉砕エネルギ 一の增大に伴い微粒化する筈であるが，2次凝集を 起こした粉粒体は見かけの粒径が大きくなり，比表 面積が減少する．前二者のような非晶性に富んだ RHA は 2 次凝集を起こしやすく, 凝集力も比較的 強いと考えられる。これに対して，後者のような RHA は結晶質に富み， 2 次凝集を起こし難く，そ

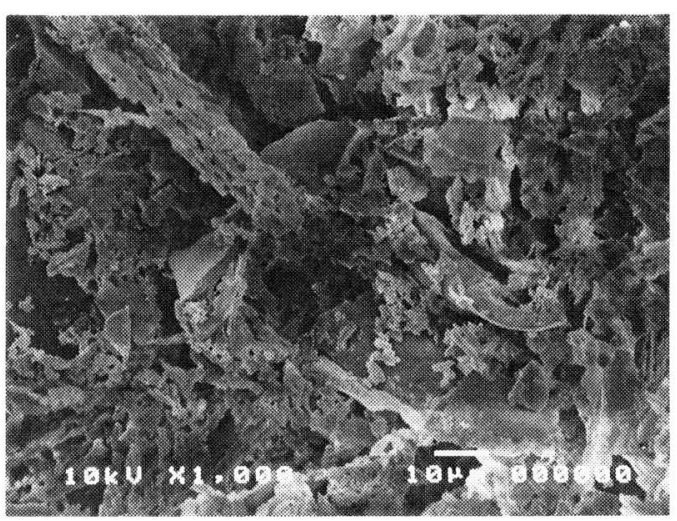

a) $\mathrm{RHA}(\times 1000)$

Method $-1: 600^{\circ} \mathrm{C}$

Grinding time: 0 min.

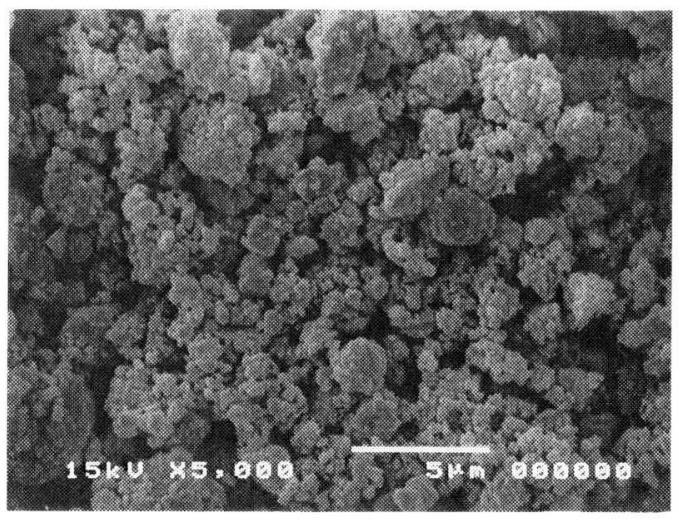

b) RHA $(\times 5000)$

Method $-1: 600^{\circ} \mathrm{C}$

Grinding time:64 min.

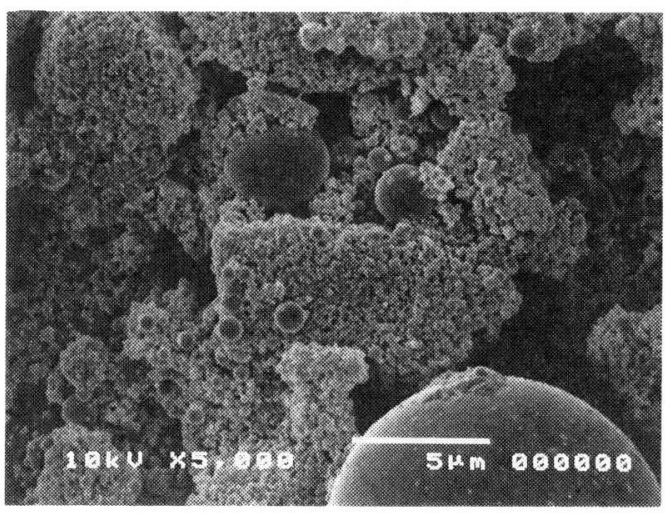

c) Silica fume $(\times 5000)$

写真-1 RHAおよびシリカフュームのSEM 


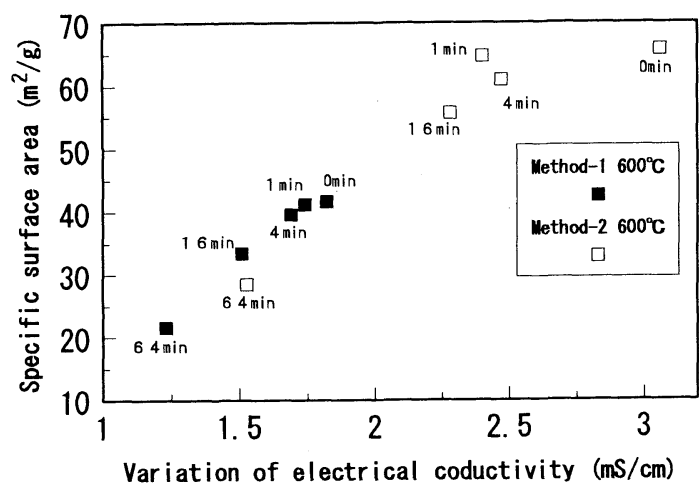

図-5 比表面積と電気伝導率差

の程度も比較的弱いと考えられる．このような差異 が図 -4のような結果をもたらしているのである. 写真 -1 に Method-1RHA の SEM写真を示した. a) は未粉砕，b) は 64 分粉砕のものであるが，後者 の場合微粒子が凝集して，ほぼ球体を構成している 様子を見ることができる。c) は比較用に示したシ リカフュームの SEM であるが，ほぼ $1 \mu \mathrm{m}$ 以下の 粒子が凝集して団塊を構成している様子を明瞭に見 ることができる。

粉体工学において，2次凝集の原因はいくつかの ものが考えられているが，何れにしても結果的には 見かけ上粉砕効果を減じ, RHAのポゾラン効果を 減少させる原因となる。

\section{（3）比表面積と正気伝学率差の関保}

上記 Method-1，Method-2 の試料について電気 伝導率を測定し， $\Delta$ 。を求めて，それらの比表面積 との関係を図ー5に示した。これによれば両者の関 係はほぼ直線的であり，伝導率測定時におけるマグ ネットスターラーの擋汼力程度では，凝集粒子が殆 ど分散しないであろうと推察される。また， Method-1 と Method-2から得られた RHAの非晶 率の相違も明らかに見ることができる.

\section{2 次较集の一軽娍法}

粉砕 RHA の 2 次凝集力が大きい場合には練り混 ぜ時において大きな問題を発生する，すなわち，モ ルタルあるいはコンクリート中での凝集粒子の分散 の問題である。この問題は RHAのみならず，シリ カフュームの場合にも存在し, これが原因でモルタ ルあるいはコンクリート供試体による活性評価がし ばしば一致しないと考えられる。シリカフュームの 凝集は写真 -1 c) に SEMの一例を示したが，この

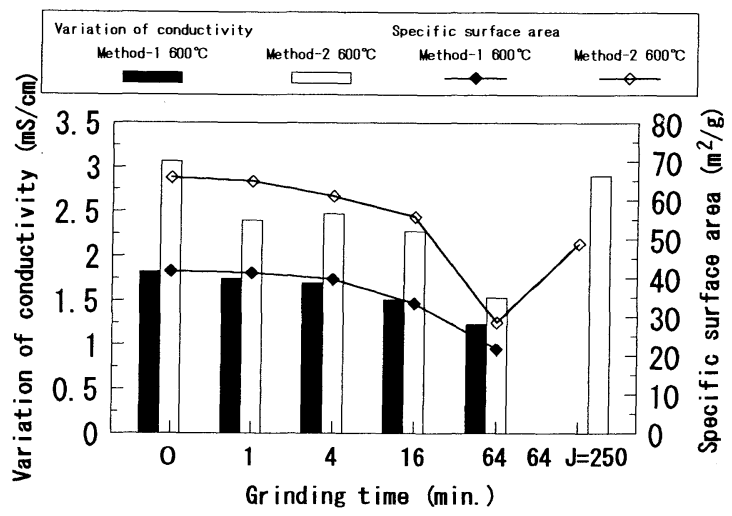

図-6 電気伝導率差, 比表面積と粉砕時間

写真によると，約 $1 \mu \mathrm{m}$ 以下の粒径を有する粒子に ついては，凝集が存在する可能性が大きいように考 えられる。したがって，練混ぜ時において凝集粒子 の分散が不十分であれば，ポゾラン活性が十分発揮 されず，活性は見掛け上低下して評価される。この ような 2 次凝集はクリンカーの粉砕時にも発生して いる ${ }^{101 ， 111}$ 。そこでこれに対する研究を参考に， 粉砕助剂を用いて RHA の粉砕を行い，その結果を 確認することとした。

図 -6 は焼却方法別に，粉砕時間別と電気伝導率 差 $\Delta_{0}$ ・比表面積の関係を棒グラフで示したもので， $\mathrm{J}=250$ は粉砕助剤としてジェチレングリコールを RHA1t 当たり $250 \mathrm{~g}$ 相当量を投入し粉砕したもので ある。 $\Delta 。(=2.90 \mathrm{mS} / \mathrm{m})$ および比表面積 $\left(=49 \mathrm{~m}^{2} / \mathrm{g}\right)$ 共顕著な増加を示している.また， この RHA を混入したモルタル（豊浦標準砂使用， 水結合材比 $55 \%$, 砂結合材比 $1.8, \mathrm{RHA}$ 混入率は セメント内割で $15 \%$ ）の 28 日圧縮強度は $61.6 \mathrm{MPa}$ を示し, 粉砕助剤を使用しない場合に比較して 20\%の增加となった。また，ジエチレングリコー ルを $125 \mathrm{~g} ， 500 \mathrm{~g}$ を加え，同様に粉砕した J=125， 500 の RHAについても $\Delta$ 。を求めたが，それぞれ $2.77 \mathrm{mS} / \mathrm{cm} ， 3.32 \mathrm{mS} / \mathrm{cm}$ であった。

このように，粉砕助剤を使用することは，2 次凝 集の軽減にかなり有効であることが示された。しか し，強度試験はモルタルを使用して試されたもので， コンクリートの場合にもこの方法が必要であるか否 かは検討することが必要である.コンクリート中に おける粗骨材の存在およびモルタルミキサに比較し て、コンクリートミキサは擋汼力がより強力である からである。 


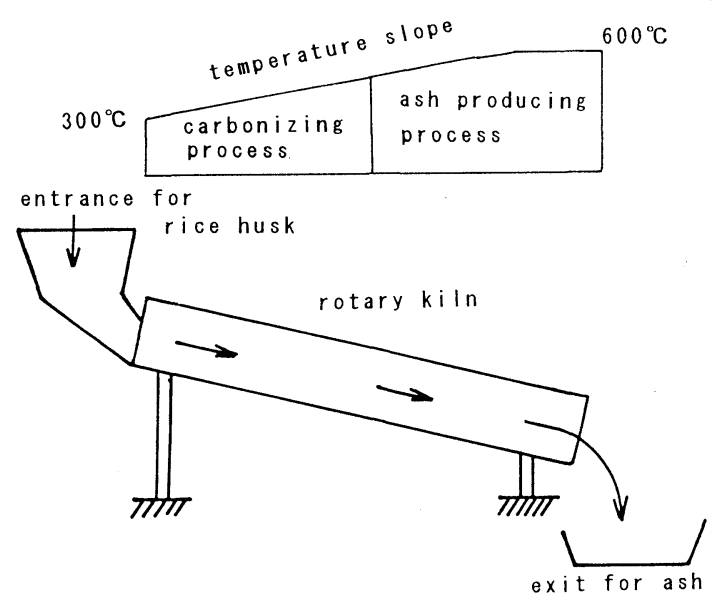

図-7 連続システム

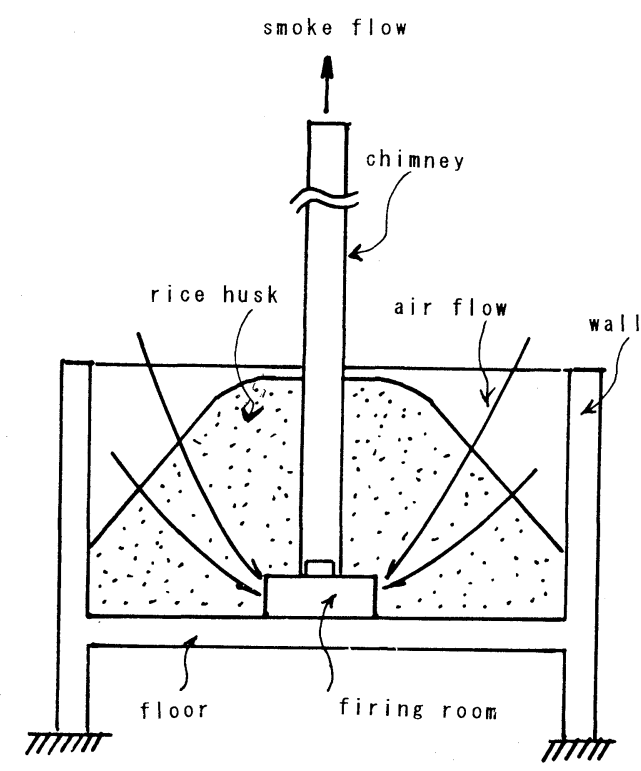

図-8バッチシステム

\section{6. 高活性 RHA 製造妒の設計}

図 -3 の結果から高活性 RHAを得るには Method-2によるのがよいことは明らかである．本 章ではこれに準拠した焼却炉の設計方法について提 案する。

\section{(1) 臬綍方式}

図-7に示すように外熱式キルンを用いる方式で ある。1本のキルンを用いて「2段階焼却法」を実 現するには，もみがら投入口付近を低温領域， RHA 排出口付近を高温領域とした温度勾配を設定 する. 前者はもみがらの炭化域, 後者は灰化域であ る. キルンの勾配は排出された RHAの状況を見な がら決定する. 実験に使用したキルンは直径 $30 \mathrm{~cm}$, 長さ $3 \mathrm{~m}$, 温度勾配 $300{ }^{\circ} \mathrm{C} \sim 600^{\circ} \mathrm{C}$, 焼却時間は 1 時間とした。得られた灰は純白の細粉であり, 電気 伝導率差は $6.3 \mathrm{mS} / \mathrm{cm}$ ときわめて大きな值が得られ た。ただ本例のように 1 本のキルン内に温度勾配を 設けると，時間経過と共に低温域の温度が次第に上 昇する. 所定温度を維持するために, 低温域にキル ンの外周から風を吹き付け $300{ }^{\circ} \mathrm{C}$ 維持した。この ように熱効率が大変低下するので，この点を改善す るために，キルンを低温部（炭化部）および高温部 (灰化部) の 2 部分に分割し, 原料の流れは連続し ている構造とするのがよいと考えている．このよう にすると熱エネルギー効率向上ともにもみがら燃焼 熱をも有効に利用しやすい，排熱をもみがらの乾燥 あるいは予熱に利用する構造も可能である。

\section{(2) パッチ方式}

この方式は最初の着火以外はもみがら焼却過程に おいて, 電気, ガス等の熱源を一切用いず, もみが ら自身の燃焼熱により焼却するものである。「2段 階焼却法」に従うことは勿論である。その断面は図 -8 に示すが, きわめて簡単な構造であり, 床, 周 壁, 着火空間, 煙突から構成されている. 着火空間 壁には小孔を多数設けてあり，着火すると火は小孔 を通してもみがらに着火する．熱せられた空気は煙 突を通して排出され, それに伴って, 外部からの空 気はもみがら層を通り抜けて着火空間に入り, 更に 煙突を通って煙と共に外部に放出される。このよう な空気と煙の流れによって, 着火されたもみがらは 発火せずに, 蒸焼き状態で燃焼が拡散する。炭化は もみがら内部から進行して表面に到り，灰化は表面 から内部へ進行する.この実験においては最高温度 は灰化時の着火空間付近に生じ, 約 $800{ }^{\circ} \mathrm{C}$ が測定さ れた。このようにして得られた RHA は灰色である が, 粉砕するとセメントあるいはシリカフュームと ほぼ同じ色合いである. 伝導率差は $2.4 \mathrm{mS} / \mathrm{cm}$ と得 られ, かなり高度のポゾラン活性が期待される值と なっている.なお, 筆者は 5 種類のシリカフューム の伝導率差を測定したが, 最大は $1.83 \mathrm{mS} / \mathrm{cm}$, 最 小は $1.01 \mathrm{mS} / \mathrm{cm}$ が得られ ${ }^{4), 5)}$, シリカフュームに 比較して, 本方法の RHA の活性が遜色のないもの であることを確認した。

\section{(3) 両方式の比較}

連続方式の場合は, キルン内でもみがらが回転・ 移動するので全体に焼きむらがなく均等に焼却でき， 
短時間の焼却で残留炭素も少なく，それ故白色の RHA が得られる。もみがら投入量, キルン勾配, 高温域の温度設定などを変えること，すなわち焼却 条件を任意にコントロールすることにより任意の性 質を有する RHA を得ることが出来る．焼却に電熱 あるいはガス等の熱源を使用するので，キルン製作 と共に生産コストは高いと考えられるが, もみがら の自己燃焼熱も考慮するとかなりの省エネルギーを 期待できると考えられる.

バッチ方式の場合は最初の着火以外は熱源を全く 必要としないので, ほぼ完全な省エネルギー型の焼 却方式である。必要な設備も図 -8 で見るように非 常に簡単なものである。一度の焼却でかなりの量の RHA を得ることができ, 焼却実験では約 $80 \mathrm{~kg}$ の実 績がある．ただ，灰化まで数日を要し，もみがらの 移動が困難なので, ある程度焼きむらが発生し, 灰 化までに長時間を要するのでキルンに比較して品質 の低下は避けられないが, 後述するように十分高活 性のもみがら灰が得られることを確認できた。焼却 条件を一定にすることで，また，「2 段階焼却法」 によると品質の温度依存性が小さいこともあり, 品 質管理は比較的容易に行えると考えられる。

何れの方式においても，もみがら投入量を多くす ると, 灰化までの所要時間が増大し, その結果高温 暴露時間が増加するので, 得られた RHAの活性は 低下する. 投入量を減少すると, 逆の結果となる.

\section{7. 高性能 RHA 製造炉から生産された RHA コンクリートの強度}

ここでは，前章で述べたバッチ方式炉から生産さ れた RHA 混入コンクリートについて述べる. 振動 式ボールミルにより 1 時間粉砕された RHAを混入 したコンクリートの強度試験により，RHAの活性 評価を行った。なお，粉砕助剤は使用していない。

\section{(1) 使用材料}

セメント：普通ポルトランドセメント 比重 3.16 細骨材: 川砂, 比重 2.66 , 吸水率 $1.26 \%$,

F.M. 2.46 , 実積率 $66.2 \%$

粗骨材：硬質安山岩砕石最大粒径 $25 \mathrm{~mm}$, 比重 2.72 , 吸水率 $0.28 \%$, F.M. 6.99 , 実積率 $57.9 \%$

$\mathrm{AE}$ 剂 : ヴィンソル

減水剂 : NL-1450

RHA : バッチ式炉生産 RHA, 粉砕 1 時間(振 動式ボールミル), 比重 $2.17, \mathrm{SiO}_{2}$ 含有率 $90.3 \%$, 強熱減量 $3.1 \%$, 伝導
表 -2 压縮強度 $(\mathrm{MPa})$

\begin{tabular}{|c|c|c|c|c|c|c|}
\hline \multirow{2}{*}{$\begin{array}{l}\text { Water bin- } \\
\text { der ratio } \\
(\%)\end{array}$} & \multirow{2}{*}{ Days } & \multicolumn{5}{|c|}{ RHA blending ratio (\%) } \\
\cline { 3 - 7 } & 0 & 10 & 20 & 30 & 40 \\
\hline \multirow{3}{*}{45} & 28 & 37.6 & 41.5 & 44.1 & 45.8 & - \\
\cline { 2 - 7 } & 91 & 43.6 & 46.6 & 48.8 & 49.8 & - \\
\hline \multirow{3}{*}{55} & 28 & 29.2 & 34.9 & 37.1 & 38.2 & - \\
\cline { 2 - 7 } & 91 & 34.2 & 39.0 & 41.0 & 42.2 & - \\
\hline \multirow{3}{*}{65} & 28 & 22.6 & 29.2 & 32.2 & 33.5 & 29.3 \\
\cline { 2 - 7 } & 91 & 26.0 & 35.7 & 36.6 & 38.5 & 34.1 \\
\hline \multirow{3}{*}{70} & 28 & 18.7 & 24.3 & 28.5 & 29.3 & 28.1 \\
\cline { 2 - 7 } & 91 & 23.0 & 29.9 & 33.4 & 36.3 & 35.0 \\
\hline
\end{tabular}

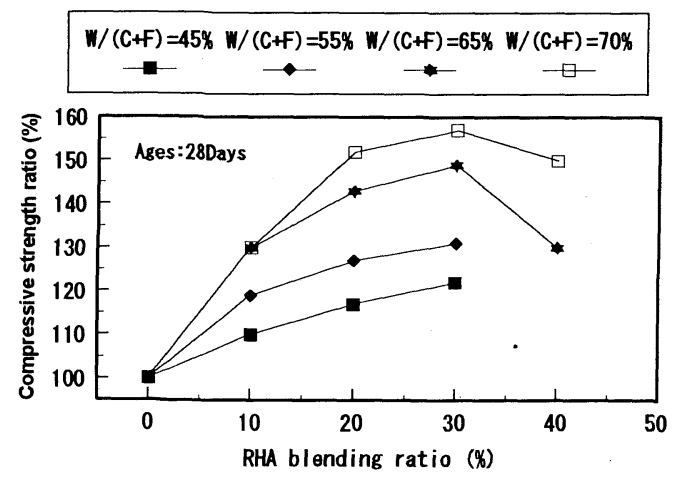

図-9 圧縮強度比とRHA混入率

$$
\text { 率差 } \Delta_{0}=2.4 \mathrm{mS} / \mathrm{cm}
$$

\section{(2) 配合}

水結合材比 : $45 \%, 55 \%, 65 \% ， 70 \%$ RHA 混入率 : $0 \% ， 10 \% ， 20 \% ， 30 \% ， 40 \%$ をセメント質量の内割

スランプおよび空気量 : 目標值 $8 \mathrm{~cm}$ および $5 \%$ 練混ぜ : ミキサは強制練りミキサ (中山式)を使用 し, 練り混ぜ時間は以下のようである。

細骨材十結合材 : 空練り 30 秒

モルタル $=$ 細骨材 + 結合材 + 水 : 1 分 30 秒

モルタル十粗骨材：2 分

なお, 単位量の決定は RHA 無混入の最適配合を 求め, RHA 混入による影響は $\mathrm{AE}$ 剂および減水凨 量を増加することによってスランプ, 空気量の調整 を行った。

\section{(3) 試験結果}

先ずフレッシュコンクリートについて述ベる．前 述の方針で行った配合であったが, 高水セメント比 
の場合は問題とするところは殆どなく，スランプお よび空気量は目標值が得られ，ワーカビリチーも良 好なコンクリートが得られた. 低水結合材比の場合 スランプと空気量は目標值が得られたが, RHA 混 入率が増加するにしたがって粘性が増大し, 円柱供 試体におけるエントラップドエアーの排除に困難な 問題が発生し，配合設計上考慮すべき問題点の存在 することが示された．何れの水結合材比においても， RHA 無混入の場合にはブリーディングを発生した が， RHA 混入の場合には全ての配合において，ブ リーディングは全く観察されなかった.ブリーディ ング抑制効果を確認することを主目的に行った水結 合材比 $70 \%$ の場合， RHA 無混入の場合には多量の ブリーディングを発生したが， RHA 混入の場合に は $10 \%$ 混入率においても全く観察されなかった。 このような完璧なブリーディング抑制効果はシリカ フュームの場合に対して説明されていると同じよう に， RHAの高非晶性と微粉効果によって初期 $\mathrm{C}-\mathrm{S}-\mathrm{H}$ ゲルが多量に生成し，これがブリーディン グ水の水途を絶つと言う説明で理解してよいと考え られる。また，凝結は水結合材比および RHA 混入 率によってがな異なるが, 全般的に早く進行する ので，施工時には遅延剂の使用も考慮することが必 要な場合もあると考えられる。

次にコンクリート圧縮強度について述ベる. 引張 ・曲げ強度については割愛する。

表 -2 は材齢 28 日および 91 日の圧縮強度を示し たものである。これを基に作成した図 - 9 は圧縮強 度と RHA 混入率の関係を材齢 28 日について，縦 軸を圧縮強度比率（RHA 無混入に対する）で示し たものである。

表 -2 と図 -9 によれば RHA 混入の効果は明瞭 である. 比率の大きさは水結合材比 $70 \%$ が最も高 く, RHA 混入率 $30 \%$ で $157 \%$ ，水結合材比 $65 \%$ で $149 \%$ ，水結合材比 $55 \%$ の場合は $131 \%$ ，水結合材 比 $45 \%$ の場合は $122 \%$ となっている.一般にポゾ ラン効果は高水セメント比ほど高いのであるが，本 実験の場合には，水結合材比 $45 \%$ および $55 \%$, RHA 混入率 $20 \%$ 以上の場合に，円柱供試体表面お よび試験後の割裂面に，目視しうる程度の気泡が認 められた。これが強度増加を阻害する一因となって いる.この点を解決すれば, より高い強度増加が得 られる.また, 特に注目してよいのは水結合材比 $70 \%$ の結果である．RHA 無混入の場合にはブリー ディングがきわめて多く，実用的観点からみると現 場における施工においては使用される機会が少ない 配合である。しかし，RHA 混入により，何れの混 入率においても全くブリーディングは見られず，圧
縮強度で比較すると, 例えば 28 日強度において混 入率 $30 \%$ で $29.3 \mathrm{MPa}$ の圧縮強度を有する。この強 度は水セメント比 $55 \%$ の RHA 無混入コンクリート の圧縮強度に匹敵するするものである．混入率 $10 \%$ の場合は $24.3 \mathrm{MPa}$ であり，これは水セメント 比 $60 \%$ の RHA 無混入コンクリート圧縮強度に相当 するものである .

このように高強度に向けての低水結合材比におい ては, 配合設計上解決すべき問題点は存在するもの の，通常の施工範囲に属する水結合材比および通常 は実構造物へ適用されることの少ない高水結合材比 の場合においても，RHAの混入によってブリーデ イングに原因する内部欠陥の少ない，しかも実用的 な強度を有するコンクリートを施工できる可能性が 示された。

もみがら灰は SEM 写真に依れば, 多くの微細孔 を有し，軟質の粉体であるから，粉砕し易いもので ある.そこで試験的に，水結合材比 $65 \%$ の場合に ついて，未粉砕 RHAを直接使用する練混ぜ実験を 行った。実験は同じ順序で材料を投入したが，結果 は超硬練り状態となり，スランプ測定あるいは締固 めが困難であった。そしてコンクリートを型枠へ詰 めた後，数十分でブリーディングを発生した。これ は粉砕 RHA のブリーディング抑制能力からは考え られない現象である.この原因は練混ぜ時の加水と 同時に，相当量の水が RHA 微細孔に吸着されたた めと考えられる. RHA の投入順序もあろうが，や はりある程度の粉砕事前処理が必要であることを示 すものである。

\section{(4) X 線回折，热豆量分析および細孔分布}

強度試験を行った後，それらの試料片を用いてX 線回折, 熱重量分析および細孔分布を測定した. 水 結合材比 $55 \%$ の結果を以下に示す.

図 -10 は X 線回折の結果である。a) は RHA 無 混入，b) は RHA30\% 混入の場合を示す.

ポゾラン効果の一つは $\mathrm{Ca}(\mathrm{OH})_{2}$ の減少であるが, a)においては明らかに $\mathrm{Ca}(\mathrm{OH})_{2}$ は検出されるので あるが，b)においては検出することが出来なかっ た。これは水和生成物として $\mathrm{Ca}(\mathrm{OH})_{2}$ が極端に少 ないことを意味し， $\mathrm{CaO}$ の殆どが $\mathrm{C}-\mathrm{S}-\mathrm{H}$ ゲルの 生成に消費されたと考えられ， C-S-H ゲルの増 加が予測される. 別の表現をすれば RHAのポゾラ ン効果が最大限度まで発揮されたといえる。この傾 向は実験を行った全ての水結合材比について同様に 認められた。

図ー11 は X線回折と同じ試料片について行った 熱分析の結果を示したものである. $500{ }^{\circ} \mathrm{C}$ 前後にお 

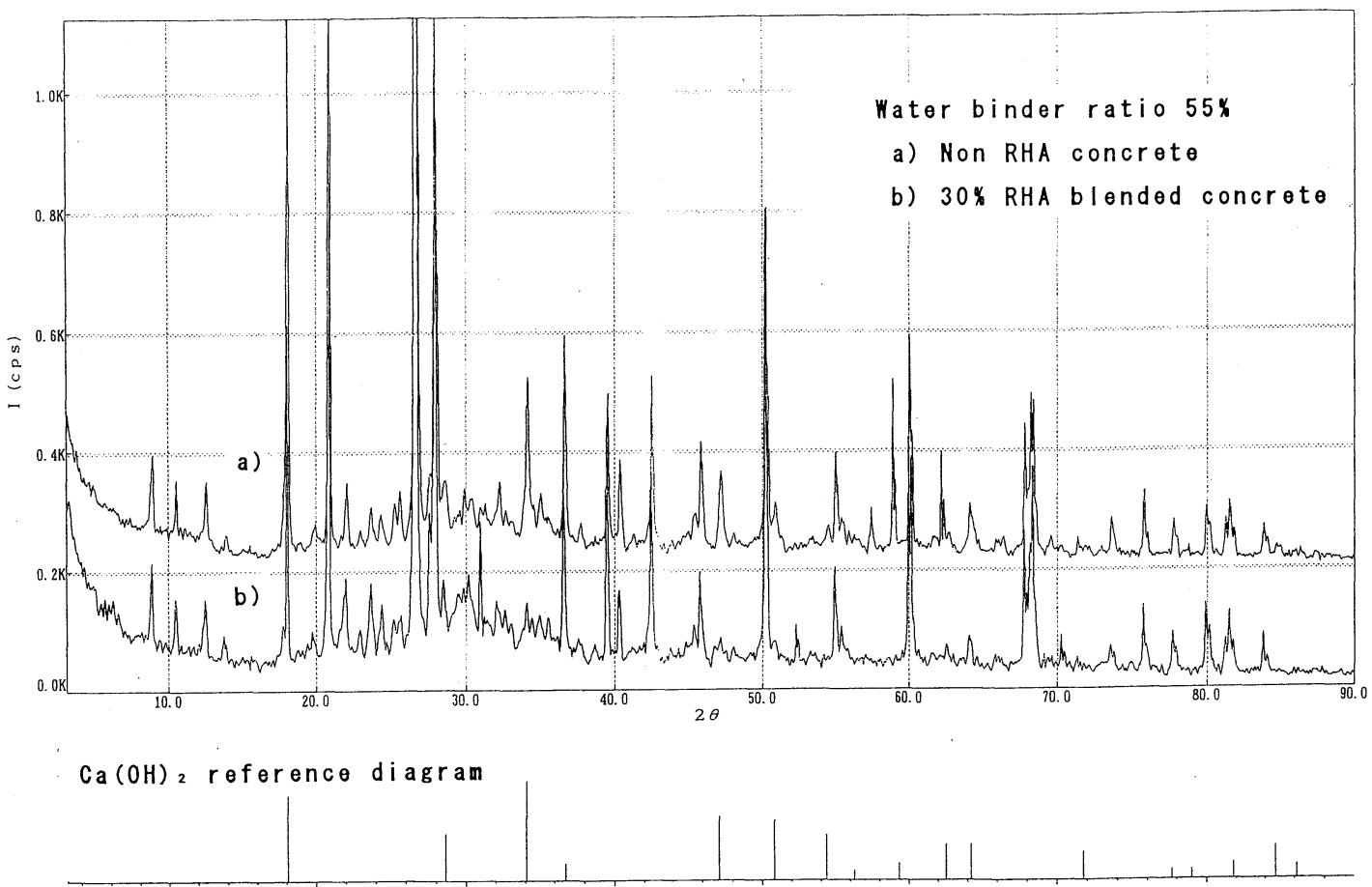

図-10 コンクリートの X 線回折図

いて見られる $\mathrm{Ca}(\mathrm{OH})_{2}$ の分解によると言われる質 量減少が RHA 無混入の場合には明瞭に観察できる が，RHA混入の場合にはきわめて微量な減少が観 察されるだけである。 $\mathrm{Ca}(\mathrm{OH})_{2}$ の分解以前および 以後は両者ともほぼ同様な傾向を示し, 最終的な質 量減少は RHA 無混入が大きく， RHA 混入の場合 が小さい。この結果は X 線回折の結果とも一致し, $\mathrm{C}-\mathrm{S}-\mathrm{H}$ ゲル増加を示すものと考えられる. 他の水 結合材比の場合についても全く同様な傾向を示して いる。

図 - 12 はやはり同じ試料片を用いて行った細孔 分布測定結果を示したものである。また，表 -3 は 測定結果の主要数值の一覧である. 全細孔量は大き な差はないが，その分布は著しく異なり，平均細孔 直径は RHA30\% 混入の場合は RHA 無混入の場合の $50 \%$ 弱である。このような内部空隙の細孔化が， 強度増進に寄与していることは明らかである。

以上述べたように，本研究の場合には全ての水結 合材比において, RHA 混入率 $30 \%$ の付近で最大の 圧縮強度を示した。換言すれば，RHAのポゾラン 活性が最高度に発揮されたと言える.そしてこのよ うなポゾラン効果が圧縮強度の増加, $\mathrm{Ca}(\mathrm{OH})_{2}$ の Water binder ratio $55 \%$

a) Non RHA concrete

b) $30 \%$ RHA blended concrete

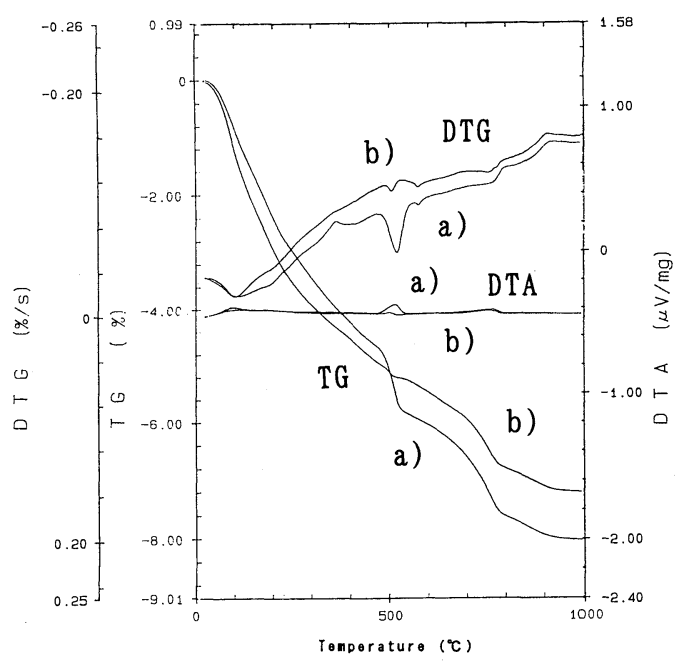

図-11 コンクリートの熱分析図 極端な減少， C-S-H ゲルの増大，および細孔化 等によって明らかにされた。このような RHA コン 


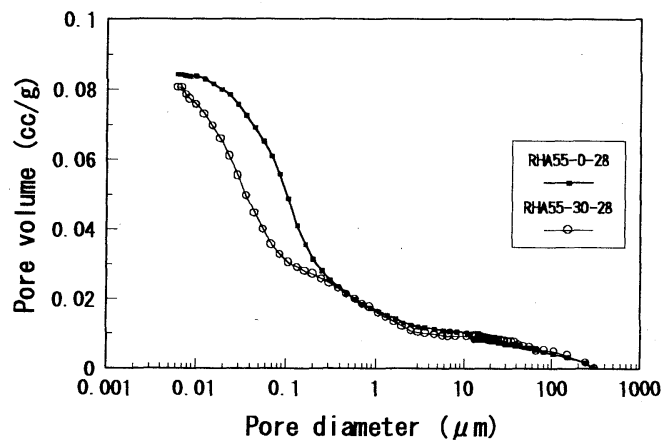

図-12 コンクリートの細孔分布

表-3 細孔分布: $W / C+F=55 \%$

\begin{tabular}{|c|c|c|c|}
\hline \multirow{2}{*}{ Item } & \multirow{2}{*}{ Unit } & \multicolumn{2}{|c|}{ Blending ratio (\%) } \\
\cline { 3 - 4 } & & 0 & 30 \\
\hline Volume & $\mathrm{cc} / \mathrm{g}$ & 0.0843 & 0.0806 \\
\hline Surface area & $\mathrm{m}^{2} / \mathrm{g}$ & 5.13 & 10.38 \\
\hline Mean diameter & $\mu \mathrm{m}$ & 0.0657 & 0.0311 \\
\hline
\end{tabular}

クリートの物理的および化学的性質など RHA コン クリートの耐久性に深く関わる問題は大変興味のあ る問題であり ${ }^{6)}$, 今後の重要な研究課題である.

\section{8. 考察とまとめ}

本研究を以下のように緾める.

1）高活性 RHA を得るためには，「2 段階焼却法」 の原理に依るのがよい。

2) RHAの非晶性の判定にはLuxanの方法が適当で ある。

3）粉砕 RHA は 2 次凝集するが，これは粉砕助剤の 使用により軽減することができる.

4）「2 段階焼却法」の原理に基づいて設計された, もみがら焼却炉の例が示された。

5）この炉から生産された RHAのポゾラン活性はき わめて高く,ブリーディング抑制能力および圧 縮強度の増加が著しい。

6) RHA 混入率 $30 \%$ 付近で最大のポゾラン効果を示 したが, 圧縮強度増加率は 57\%(水結合材比 $70 \%), \mathrm{Ca}(\mathrm{OH})_{2}$ は殆ど観察されず，平均細孔
径は RHA 無混入の場合の $50 \%$ 弱である.

7) 水結合材比 $70 \%$ の場合で示されたように，RHA のブリーディング抑制能力および圧縮強度の増 加により， RHAの混入によって在来のコンク リートの水セメント比の適用範囲を拡大するこ とができる.

謝辞：本研究に当たり，八戸セメント（株）常務 取締役 林 宣孝氏および住友セメント（株）中央 研究所 五十畑 達夫氏からは貴重な助言と助力を 与えて戴いた。記して感謝致したい。

\section{考支献}

1) P.K. Mehta: Properties of Blended Cement Made from Rice Husk Ash, ACI Journal, 74-9, pp.440-442, 1977.

2) Y.Yamamoto and S.M. Lakho: Production and Utilization of Active Rice Husk Ash as a Substitute for Cement, Proc.of JSCE, No.32, pp.157-16 6, June, 1982.

3）特許公報(B2)，昭60-13991.

4）杉田, 庄谷, 徳田：もみがら灰のポゾラン活性につ いて, 土木学会 第 45 回年次学術講演会，部門， pp.202-203, 1990.

5) S.Sugita, M.Shoya and H.Tokuda: Evaluation of Pozzolanic Activity of Rice Husk Ash, 4th CANMET/ ACI Int. Conf. on Fly Ash Silica Fume, Slag and Natural Pozzolans in Concrete Istanbul, Turkey, May 1992, SP $132-28$.

6）阿波，庄谷，杉田：もみがら灰を用いたコンクリー 卜の品質に関する基礎的研究, 土木学会第 47 回年次 学術講演会, V部門, pp.692-693, 1992.

7）杉田，庄谷，磯島：高活性もみがら灰製造法とそれ を用いたコンクリートの性質, コンクリートエ学年 次論文報告集，Vol.15, No. 1, pp.321-326, 1993.

8) S.Sugita, M.Shoya, Shi P.and Y.Isojima: Design of Furnace for Large Quantities of Highly Active Rice Husk Ash, The 3rd Beijing Int. Symposium on Cement and Concrete, Vol.2, pp.651-655, Oct., 1993

9) M.P. Luxan et al: Rapid Evaluation of Pozzolanic Activity of Natural Products by conductivity Measurement, Cement Concrete Research, Vol.19, pp.63-68, 1989

10）岩淵, 下林, 鈴木: ジェチレングリコールがセメン トの諸品質におよほす影響，セメント技術年報 XXIII, pp.163-169, 1969.

11）岩淵：セメントの粉砕助㓮に関する補遺的研究， セメント技術年報 XXIV，pp.139-147，1970。

12）荒井 康雄: 粉体の材料化学, pp.64, 培風館, 1988.

13）作花 済夫：アモルファス，共立出版社， 1986 .

(1994.11.28受付) 


\section{A FUNDAMENTAL STUDY ON THE EFFECTIVE USE FOR RICE HUSK ASH AS A POZZOLANIC MATERIAL}

\section{Shuichi SUGITA and Masami SHOYA}

Chemical activity of rice husk ash is greatly controlled by the burning condition for rice husks. In this report a burning principle that is named "Two Step Burning Method" and two examples of furnace based on the principle were shown. The rice husk ash produced from these furnaces was very active, and it was confirmed by compressive strength test for concrete specimens. Furthermore, some physical properties for secondary agglomeration of ground rice husk ash were studied. The agglomeration causes to block the dispersion of ground rice husk ash when concrete is mixed. A grinding aid(di-ethylene glycol)was used to prevent that. It was also shown that theuse of the grinding aid was so effective to prevent the agglomeration. Highly active rice husk ash was also very effective to prevent bleeding of fresh concrete even in the case of water binder ratioof $70 \%$. No bleeding was observed, and concrete which had ractical strength for concrete structure was obtained. 